\title{
A pilot study examining the perceived effectiveness of fi- nancial education in high school and the effect on per- sonal financial behavior of the young generation
}

\author{
Brian Tung* \\ The Hang Seng University of Hong Kong, Hong Kong, China
}

\author{
Keywords \\ Financial literacy \\ Financial behavior \\ Personal financial knowledge \\ Received: 4 February 2019 \\ Accepted: 5 March 2019 \\ Published: 24 April 2019
}

\begin{abstract}
This study aims to shed light on the possible research design to investigate whether young generation are well prepared with the basic financial knowledge to handle the personal finance issues. A pilot study is conducted to investigate whether there is a difference between teachers' and students' perception of the effectiveness of financial education in high schools and the need to provide personal finance education programs at higher education institutions. Preliminary hypotheses testing was conducted to explore the relationship between age, personal financial knowledge, and personal finance behavior of the high school and tertiary level students. Validated measurement scale items are adopted, and Hong Kong is chosen for the investigation. The results revealed that students and other stakeholders share the same view about financial education programs' effectiveness and the needs of such training at the higher education level. While taking financial education training could enhance financial literacy, doing so seems not a good predictor of financial behavior, so as the age and financial literacy level. The experience of this pilot study and the implication of these preliminary findings can support the design of a fuller scale of research by informing policymakers, education sectors, and social science on the need to identify possible factors affecting the financial behavior of the young generation. It will also help design highly targeted and well-specified programs to support them in managing financial matters for the well-being of the individuals and society.
\end{abstract}

(C) 2019 The Author(s). Published by TAF Publishing

\section{INTRODUCTION}

This study is going to investigate the difference between teachers' and students' perception of the effectiveness of financial education in high schools. Additionally, the study will find out how strong the relationship between age, personal financial education, knowledge and personal finance behavior of the tertiary level students are.

The motivation for the study is because the young generation nowadays are exposed to active promotion of financial services. In cities with high tertiary education popularization rate, because of their higher consumption and finance potential after graduation, the young generation had become a target segment of retailers, credit card providers and other sectors such as banking and finance. However, the lack of financial literacy and the insufficient awareness of the risks of overspending may lead the youths mak- ing poorly-informed personal financial decisions which will have a knock-on effect in their future.

Although some high school students have taken courses related to financial management, the effectiveness of such courses in supporting the young generation to adopt proper financial behavior is not clear because previous research focused on teachers' perception, while students view was not fully considered. In addition, the assumed correlation of having higher financial literacy level and more proper personal financial behavior is not fully investigated. More important, the relationship between personal financial knowledge and personal finance behavior of the tertiary level students deserves more careful investigation.

To fill the research gap, a pilot study is conducted. Hong Kong, the Asia's major financial center, was chosen for the investigation. Selected validated measurement scale items

*corresponding author: Brian Tung

†email: briantung@hsu.edu.hk 
were applied. The rationale is to take the pilot study as a precursor to determine the potential value of a full-scale empirical investigation and to pre-test the research instrument and administration design for such larger scale investigation.

Besides filling the research gap mentioned above, the pilot study design is also important by exploring how to strike a balance between doing reliable investigation and securing reasonable response rate with target respondents be the student population in cities with fast pace of life and tight study schedules which makes too long or too complicated questionnaire items less effective.

Six hypotheses will be developed from literature review to study whether there is difference between teachers' and students' perception of the effectiveness of financial education in high schools, and how strong the relationship between age, personal financial education, knowledge and personal finance behavior of the tertiary level students are.

\section{LITERATURE REVIEW, RESEARCH GAPS AND HYPOTHE- SES}

\section{Financial Literacy}

Financial literacy is a combination of awareness, knowledge, skill, attitude and behaviour necessary to make sound financial decisions (International Network on Financial Education, 2011; Masuo \& Cheang, 2017). Past literatures also defined financial literacy within similar competency aspects (Lusardi, Mitchell, \& Curto, 2010; Taft, Hosein, Mehrizi, \& Roshan, 2013; Stone, Wier, \& Bryant, 2008). Promoting financial education is now being regarded by the private, public and civil stakeholders as an essential long-term human capital investment. Various academic research disciplines such as social science, financial education, financial behavior, as well as banking and finance coincidentally focused on financial literacy related issues.

\section{Perceived Effectiveness of Financial Education}

High schools' teachers normally believe there is value to offer financial education courses at high schools. Previous research found this is a common belief in European countries (Lechner et al., 2018). Take Hong Kong as another example, teachers expressed that the learning needs of students in financial education are not addressed holistically, and they held the view that related courses are required at high schools (Investor Education Centre, 2014). Although teachers' view on the usefulness of financial education for students is quite conclusive, the investigation of students' perception is still rare. Yet, some educational research e.g., (Nolen \& Haladyna, 1990) found teachers affect students' beliefs. Because of this, Hypothesis 1 is developed.

H1: Teachers, students and other stakeholders have the same perception of the effectiveness of financial education at high schools in supporting youngsters to handle personal finance issues.

\section{Perceived Needs of Financial Education in Higher Edu- cation Institutions}

Previous research confirmed that college students considered that financial education services and counseling should be made available to them (Goetz, Cude, Nielsen, Chatterjee, \& Mimura, 2011). Courses that could introduce more financial knowledge are perceived as useful by young people (Lusardi et al., 2010). This is expected other stakeholders will express the same view that there is a need to have personal finance subject offered in higher education institutions because young people encounter more complex personal financial issues when growing up. Their interest in having the higher education institutions providing financial education to university students increased because many findings confirmed university students lack financial management skills (Atakora, 2013; Nellie, 2002; Norvilitis et al., 2006). Therefore, Hypothesis 2 is developed.

H2: Teachers, students and other stakeholders have similar view that personal finance subject should be offered in higher education institutions for all their students.

\section{Financial Education and Financial Literacy}

Financial literacy level is found to be affected by education level and attending training classes and courses in personal finance, business or economics (Albeerdy \& Gharleghi, 2015; Chen \& Volpe, 2002; Cude, 2010; Kamran \& Z, 2016; Lusardi et al., 2010; Peng, Bartholomae, Fox, \& Cravener, 2007; Taft et al., 2013). Various financial literacy curriculum reported improving students' financial knowledge (Asarta, Hill, \& Meszaros, 2014; Danes \& Haberman, 2007; Varcoe, Martin, Devitto, \& Go, 2005; Walstad, Rebeck, \& MacDonald, 2010). However, there is still voice calling for more evidence support of financial education effectiveness (Isomidinova, Singh, \& Singh, 2017; Lusardi \& Tufano, 2009). Therefore, Hypothesis 3 and 4 are developed to address such call to grow the literature.

H3: Students taking finance related courses or activities at high schools have higher financial literacy.

H4: Students taking finance related courses or activities in university have higher financial literacy. 


\section{Financial Literacy and Financial Behavior of Tertiary Level Students}

Previous research found that a high level of financial literacy has a positive impact on management of personal finances (Capuano \& Ramsay, 2011; Lusardi et al., 2010). But those previous researches mainly focused on adults but not the youths such as university students. Their applicability and generalizability to this specific research context remains unclear.

In addition, there is a branch of financial literacy research associating "financial literacy overconfidence" with financial behavior. The concern is the overconfident people may indicate they understand advice or financial products when they do not in reality (De Zwaan, Palm, Liu, \& Chardon, 2017; Yilmaz, 2017). Whether youngsters after taking fundamental courses in financial education resulting in overconfidence towards financial matters and making improper decision is a concern. Because of these inconclusive findings, Hypothesis 5 is developed to explore whether there is correlation between financial literacy and financial behavior.

H5: There is correlation between financial literacy and financial behavior for tertiary level students.

\section{The Effect of Age, Financial Education and Financial Lit- eracy on Financial Behavior}

Financial behavior refers to any human behavior relating to money or financial resources management, such as planning, budgeting (Xiao, 2008; Zakaria, Jaafar, \& Marican, 2012).

Previous studies on financial literacy tried to identify other factors has association with financial literacy level, such as age and levels of education (Cude, 2010; Taft et al., 2013).
However, their investigation rarely investigated the causality of those factors with financial behavior.

Previous research showed that, besides the change in financial literacy, there will be behavioral change by taking Financial literacy programme (Danes, Huddleston-Casas, \& Boyce, 1999). However, such investigation focused only on a short-term impact after taking those courses. Whether the effect could sustain for longer period of time is not certain. In addition, there are also previous findings concluded that financial education may not always result in behavior change because of other constraints or interfering factors such as income (Seiling \& Shockey, 2006).

Although previous research focused on the correlation or causality of financial literacy level and financial behavior e.g., (Courchane \& Zorn, 2005; Hilgert, Hogarth, \& Beverly, 2003; Kotlikoff, 2016), youths were not the research focus. For youngsters in the new era, they are expected to be easily influenced by marketing promotion that stimulate their consumption and credit card usage. Whether those regular marketing stimuli could offset the effect of financial literacy factors deserves more investigation.

Putting the above together, to contribute a better understanding of the effect of Age, Financial Education and Financial literacy on Financial Behavior of the youth, Hypothesis 6 is developed.

H6: Age, taking finance related subject in high school and financial literacy level are significant predictor of financial behavior.

\section{Theoretical Framework}

The following diagram summarizes the causal relationships this pilot study intents to explore based on the above literature review and hypotheses development.

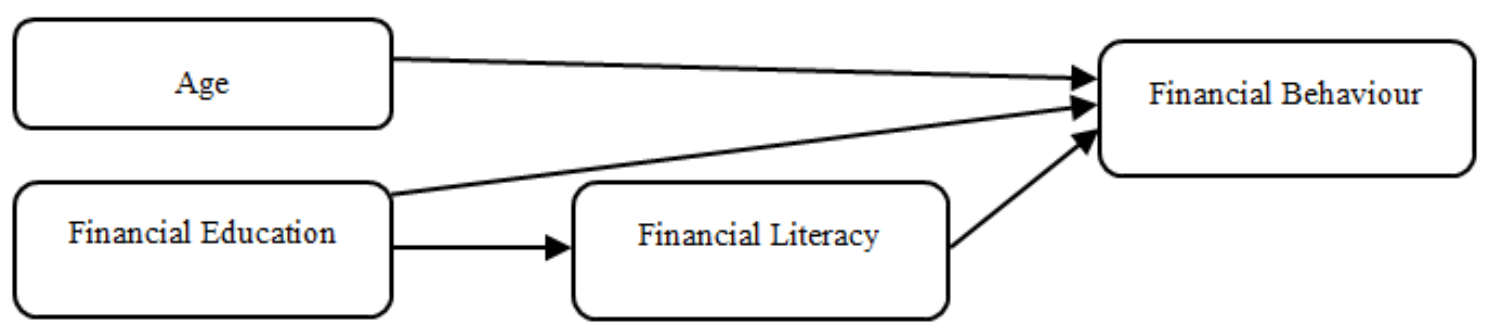

FIGURE 1. Research framework

\section{RESEARCH DESIGN}

Before conducting a full-scale research investigation, pilot test is recommended for the purpose of the research instrument pre-testing and the administration design of a large scale investigation (Gudmundsdottir \& Brock-Utne, 2010). A pilot test is conducted to serve the following purposes: (1) as a precursor to determine the potential value of the empirical investigation of the above hypotheses which are developed from literature review, (2) to confirm target respondents' comprehension of the questionnaire items, (3) to explore if the design of the survey administration procedures, the length of the survey and the data collection processes appropriate for student population in cities with fast pace of life and tight study schedules.

Since the investigation involve checking financial knowledge of the respondents, online survey is not recommended 
because there is a worry that respondents may search online for the "correct answers" to those questions and affect the research results. The pilot survey was conducted at the end of a forum related to financial literacy issues of high school and university students. Audience included high school students, teachers, university students and other stakeholders such as students' counsellors. They are the relevant respondents this investigation targeted at. The forum was conducted in a chamber of a private university in Hong Kong in an afternoon during normal academic semester. The duration of the forum was approximately two hours, which are typical for co-curricular activities constrained by the tight and compact study load and curriculum design. Such context poses a challenge to secure an acceptable response rate and completion rate of a questionnaire survey. Too long or too complicated questionnaire items may discourage respondents from completing the survey or ensure their effective interpretation of the survey items, while minimizing the number of questions may negatively affect the power of statistical tests for the proposed hypotheses.

Taking the above in mind, two measurement items were developed to investigate respondents' view on the effectiveness of finance related subjects at high schools and whether personal finance subjects should be offered at university level. 5-point Likert scale ranging from strongly agree to strongly disagree were used in these two questions: "Finance related subject(s) at secondary school level can support youngsters to handle personal finance issues at tertiary level" and "Personal Finance subject should be offered in higher education institutions for all students".

Validated closed-end quantitative measurement scale items developed by the Jump\$tart Coalitation for Personal Financial Literacy were adopted to measure financial literacy and self-reported financial behavior. For the latter one, there are items covering various aspects of self-beneficial financial behavior (Hilgert et al., 2003; Mandell \& Klein, 2009; Robb \& Sharpe, 2009). Given the busy pace of life in Hong Kong, the lengthy items are selectively chosen to ensure better response rate. Five questions for self-reported financial behavior were adpoted. They are:

- "How would you rate the savings and investments that you have?"

- "How much do you worry about your financial condition?"

- "How many credit cards do you use, including store credit cards?"

- "Always pays credit card in full?"

- "Often make late credit card bills payment?"

Three questions were for financial literacy with correct and incorrect answers are provided for choosing. They are:

- "Which of the following types of investment would best protect the purchasing power of a family's savings in the event of a sudden increase in inflation?"

- "Which of the following loans is likely to carry the highest interest rate?"

- "A high-risk and high return investmen strategy would be most suitable for:.."

Four questions were used to learn the respondents background such as their roles (e.g., students, teachers, students' counsellors, etc.), year of study if they were students (e.g., high school or year- 1 at higher education, etc.), finance subjects or related co-curricular activity taken (if any), as well as their gender.

Printed copies of the questionnaire were inserted into the information kit of the forum and were distributed to the attendees at the beginning of the event. Before the end of the events, attendees were invited to this self-administered survey on a voluntary and anonymous basis. Attendees were encouraged to ask for clarification if they did not understand the questionnaire items.

Data from the completed questionnaires were input into Statistical Package for the Social Sciences(SPSS) computer program. Independent samples $t$-test, one-way ANOVA, correlation and multiple regression analysis were undertaken by using SPSS to explore the feasibility of using the survey questionnaire to test the hypotheses. The following section provides the details.

\section{FINDINGS AND PRELIMINARY ANALYSES FROM THE PI- LOT STUDY \\ Comprehension of Questionnaire and Administration Design}

As mentioned above, this pilot study is for the purpose of the research instrument pre-testing and the administration design of a large-scale investigation. Specifically, it aims to confirm target respondents' comprehension of the questionnaire items, and to explore if the design of the survey administration procedures, the length of the survey and the data collection processes appropriate for student population in cities with fast pace of life and tight study schedules. During the data collection process, no enquiry was received from the respondents although they are highly encouraged to do so. A response rate of approximately $75 \%$ was finally achieved. It was mainly due to the early leave of some of the attendees before the end of the forum without filling the questionnaire. The questionnaire collected back were manually check for completeness. There was no uncompleted copy. 39 filled completed and usable questionnaires were 
secured. These implies the respondents' comprehension of the questionnaire was satisfactory. Also, the length of the survey was appropriate.

The following presents the background of the respondents and the preliminary hypotheses testing results.

\section{Descriptive Statistics}

Most of the respondents are students (89.7\%) and the rest are teachers and counsellor. Among the students, most of them are university year one students (69\%). Most of the students have taken subjects related to finance at high school. 3 students studying year- 2 in the university are major in business and have taken a finance related subject "Financial management". Table 1 shows the details.

TABLE 1. Descriptive statistics

\begin{tabular}{|c|c|c|c|c|}
\hline & Frequency & Percent & Valid Percent & Cumulative Percent \\
\hline & & Background of the respondents & & \\
\hline Valid Students & 35 & 89.7 & 89.7 & 89.7 \\
\hline Teacher/lecturer & 3 & 7.7 & 7.7 & 97.4 \\
\hline counsellor & 1 & 2.6 & 2.6 & 100.0 \\
\hline \multirow[t]{2}{*}{ Total } & 39 & 100.0 & 100.0 & \\
\hline & & Background of the students & & \\
\hline Valid F5 & 5 & 12.8 & 14.3 & 14.3 \\
\hline Yr1 & 27 & 69.2 & 77.1 & 91.4 \\
\hline yr2 & 3 & 7.7 & 8.6 & 100.0 \\
\hline Total & 35 & 89.7 & 100.0 & \\
\hline Missing System & 4 & 10.3 & & \\
\hline \multirow[t]{2}{*}{ Total } & 39 & 100.0 & & \\
\hline & & Subjects Taken at High School of the students & & \\
\hline Valid Eco & 10 & 25.6 & 28.6 & 28.6 \\
\hline BAFS & 20 & 51.3 & 57.1 & 85.7 \\
\hline co-act & 2 & 5.1 & 5.7 & 91.4 \\
\hline NIL & 3 & 7.7 & 8.6 & 100.0 \\
\hline Total & 35 & 89.7 & 100.0 & \\
\hline Missing System & 4 & 10.3 & & \\
\hline Total & 39 & 100.0 & & \\
\hline
\end{tabular}

Perception of Students and Other Stakeholders on the Effectiveness of Financial Education at High Schools in Supporting Youngsters to Handle Personal Finance Issues

A one-way analysis of variance was conducted to examine the perception differences between students and non- students regarding the effectiveness of financial education at high schools in supporting youngsters to handle personal finance issues performance ratings of followers. One-way Analysis of variance gives a single overall test of whether there are differences between groups (Bewick, Cheek, \& Ball, 2004; Carnevale, 2003).

TABLE 2. ANOVA test for hypothesis 1

\begin{tabular}{|c|c|c|c|c|c|c|c|c|}
\hline \multicolumn{9}{|l|}{ Descriptives } \\
\hline \multicolumn{9}{|c|}{ Subject Can Support_7 } \\
\hline & \multirow[t]{2}{*}{$N$} & \multirow[t]{2}{*}{ Mean } & \multirow[t]{2}{*}{ Std. Deviation } & \multirow[t]{2}{*}{ Std. Error } & \multicolumn{2}{|c|}{ 95\% Confidence Interval for Mean } & \multirow[t]{2}{*}{ Minimum } & \multirow[t]{2}{*}{ Maximum } \\
\hline & & & & & Lower Bound & Upper Bound & & \\
\hline Students & 35 & 3.31 & 1.022 & .173 & 2.96 & 3.67 & 1 & 5 \\
\hline Teacher/lecturer & 3 & 4.33 & .577 & .333 & 2.90 & 5.77 & 4 & 5 \\
\hline Counsellor & 1 & 4.00 & . & . & . & . & 4 & 4 \\
\hline Total & 39 & 3.41 & 1.019 & .163 & 3.08 & 3.74 & 1 & 5 \\
\hline
\end{tabular}




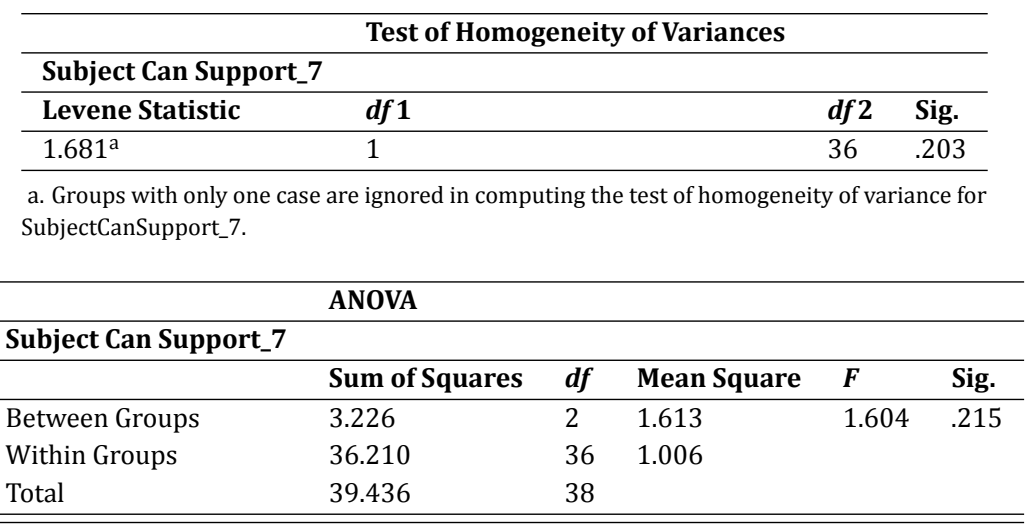

SPSS outputs are shown in Table 2. The means and standard deviations are shown in the Tables. The homogeneity of variance assumption was not violated according to the Levene's test $(F=(1.36)=1.681, p>.05)$. Both teachers, students and other stakeholders have similar view on the effectiveness of those subjects in supporting youngsters to handle personal finance issues $F(2.36)=1.603, p>.05$. The overall mean 3.41 means "neutral" to "agree".

Perception of Students and Other Stakeholders on The Needs of Personal Finance Subject to be Offered in Higher Education Institutions

A one-way analysis of variance was conducted to examine the perception differences between students and non- students regarding the effectiveness of financial education at high schools in supporting youngsters to handle personal finance issues performance ratings of followers. One-way Analysis of variance support the comparison the difference between groups (Bewick et al., 2004). The means and standard deviations were shown in Table 3. The homogeneity of variance assumption was not violated aoocrding to the Levene's test $(F=(1.36)=0.915, p>.05)$. No significant difference was found $F(2,36)=1.574, p>.05$. Both teachers, students and other stakeholders have similar view that personal finance subject should be offered in higher education institutions for all their students (overall mean 3.82 inclines towards "agree").

TABLE 3. ANOVA test for hypothesis 1

\begin{tabular}{|c|c|c|c|c|c|c|c|c|}
\hline \multicolumn{9}{|l|}{ Descriptives } \\
\hline \multicolumn{9}{|c|}{ ShouldOffer@HE_8 } \\
\hline & $N$ & Mean & Std. Deviation & Std. Error & \multicolumn{2}{|c|}{ 95\% Confidence Interval for Mean } & Minimum & Maximum \\
\hline Students & 35 & 3.74 & .886 & .150 & 3.44 & 4.05 & 2 & 5 \\
\hline Teacher/lecturer & 3 & 4.67 & .577 & .333 & 3.23 & 6.10 & 4 & 5 \\
\hline Counsellor & 1 & 4.00 & . & . & . & . & 4 & 4 \\
\hline Total & 39 & 3.82 & .885 & .142 & 3.53 & 4.11 & 2 & 5 \\
\hline
\end{tabular}

\begin{tabular}{llll}
\hline \multicolumn{5}{c}{ Test of Homogeneity of Variances } \\
\hline ShouldOffer@HE_8 & & $\boldsymbol{d f} \mathbf{2}$ & Sig. \\
\hline Levene Statistic & $\boldsymbol{d} \boldsymbol{f} \mathbf{1}$ & 36 & .345 \\
\hline $.915^{\mathrm{a}}$ & 1 & 36
\end{tabular}

a. Groups with only one case are ignored in computing the test of homogeneity of variance for ShouldOffer@HE_8.

\begin{tabular}{llllll}
\hline \multicolumn{7}{c}{ ANOVA } \\
\hline ShouldOffer@HE_8 & \multicolumn{1}{l}{ @um of Squares } & $\boldsymbol{d f}$ & Mean Square & $\boldsymbol{F}$ & Sig. \\
\hline & Sum & 2 & 1.196 & 1.574 & .221 \\
Between Groups & 2.391 & 36 & .760 & & \\
Tithin Groups & 27.352 & 38 & & & \\
\hline \hline
\end{tabular}


Impact of Financial Education Courses on Financial Literacy at High School Level

The impact of financial education courses on high school students was examined by an independent samples $t$-test, which could examine existence of differences between the two groups (Ansong \& Gyensare, 2012; Taft et al., 2013). Levene's test supported the assumption of homogeneity of variance $(F=0.96, p>.05)$. The analysis indicated that the financial literacy level of students taking (or have taken) subjects related to finance significantly better than their counterparts without taking those subjects $(t=1.79, p<.05$ because of one-tailed hypothesis). The finding supported Hypothesis 3. Table 4 shows the related SPSS outputs.

TABLE 4. Independent samples $t$-test for hypothesis 3

\begin{tabular}{|c|c|c|c|c|c|}
\hline & \multicolumn{5}{|l|}{ Group Statistics } \\
\hline & Take_notTake & $N$ & Mean & Std. Deviation & Std. Error Mean \\
\hline over all Knowledge & 1.00 & 32 & 1.5938 & .87471 & .15463 \\
\hline & .00 & 3 & .6667 & .57735 & .33333 \\
\hline
\end{tabular}

\begin{tabular}{|c|c|c|c|c|c|c|c|c|c|c|}
\hline \multicolumn{11}{|c|}{ Independent Samples Test } \\
\hline & & \multicolumn{2}{|c|}{$\begin{array}{l}\text { Levene's Test for } \\
\text { Equality of Variances }\end{array}$} & \multicolumn{5}{|c|}{$\begin{array}{l}t \text {-Test for } \\
\text { Equality of Means }\end{array}$} & \multicolumn{2}{|c|}{$\begin{array}{l}95 \% \text { Confidence } \\
\text { Interval of the Difference }\end{array}$} \\
\hline & & $F$ & Sig. & $t$ & $d f$ & $\begin{array}{l}\text { Sig. } \\
\text { (2-Tailed) }\end{array}$ & $\begin{array}{l}\text { Mean } \\
\text { Difference }\end{array}$ & $\begin{array}{l}\text { Std. Error } \\
\text { Difference }\end{array}$ & Lower & Upper \\
\hline \multirow[t]{2}{*}{$\begin{array}{l}\text { Over all } \\
\text { Knowledge }\end{array}$} & $\begin{array}{l}\text { Equal variances } \\
\text { assumed }\end{array}$ & .963 & .334 & 1.786 & 33 & .083 & .92708 & .51905 & -.12893 & 1.98309 \\
\hline & $\begin{array}{l}\text { Equal variances } \\
\text { not assumed }\end{array}$ & & & 2.523 & 2.945 & .088 & .92708 & .36745 & -.25486 & 2.10903 \\
\hline
\end{tabular}

\section{Impact of Financial Education Courses on Financial Lit-} eracy at University Level

The impact of financial education courses on university students was examined by an independent samples $t$-test, which could examine existence of differences between the two groups (Ansong \& Gyensare, 2012; Taft et al., 2013). As shown in Table 5, homogeneity of variance assumption was not supported by Levene's test $(F=9.76, p<.05)$. The analy- sis informed that the financial literacy level of students taking (or have taken) subjects related to finance in university is significantly better than their counterparts without taking those subjects $(t=-3.53, p<.01)$. The financial literacy of Year-1 students not yet taking related subject (mean = 1.37, S.D. $=.93$ ) is lower than the Year-2 students taking or already taken related subject (mean $=2, S . D .=.00)$. Hypothesis 4 was therefore supported.

TABLE 5. Independent Samples $t$-test for hypothesis 4

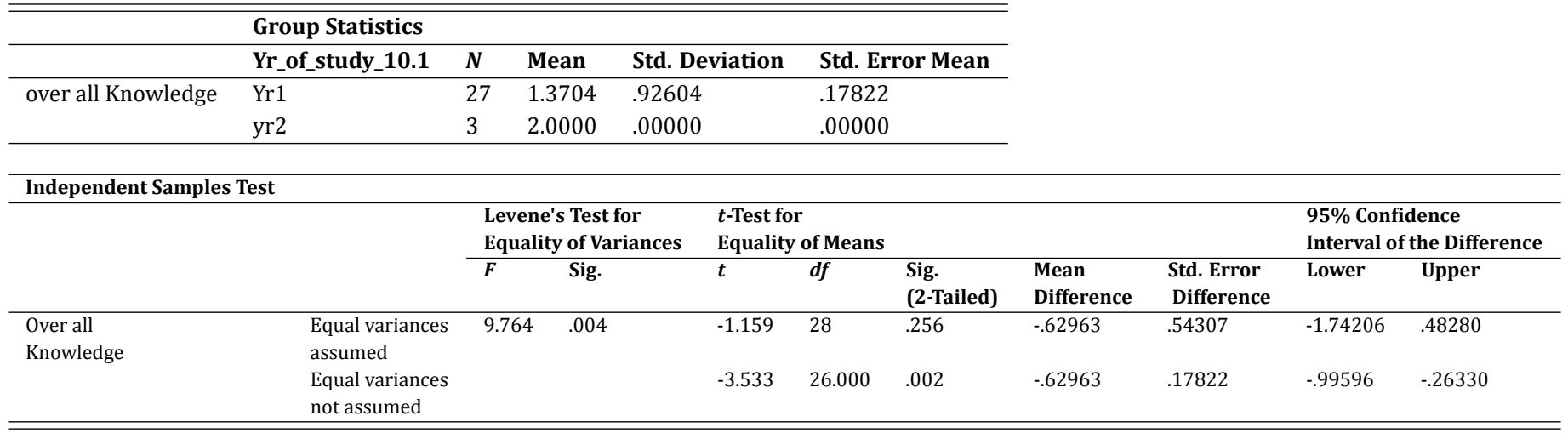

\section{Correlation between Financial Literacy and Financial Behavior of Tertiary Level Students}

The correlation between financial literacy and financial behavior was investigated by the Pearson product-moment correlation analysis for student respondents with credit card because the usage and repayment habit reflect more about behaviour. This analysis technique is used because it supports the investigation of the relationship strength between two continuous variables (Albeerdy \& Gharleghi, 2015; Isomidinova et al., 2017). Hypothesis 5 is not supported because financial literacy and financial behavior has non-significant correlation $(r=.335, p>.05)$ thereby not supporting the Hypothesis 5. 
TABLE 6. Pearson product-moment correlation analysis for hypothesis 5

\begin{tabular}{|c|c|c|c|c|c|}
\hline \multicolumn{6}{|c|}{ Descriptive Statistics } \\
\hline & Mean & \multicolumn{2}{|c|}{ Std. Deviation } & $N$ & \\
\hline Over all Knowledge & 1.4000 & \multicolumn{2}{|c|}{.73679} & 15 & \\
\hline Sum_All_Behavior & 18.8667 & \multicolumn{2}{|c|}{1.50555} & 15 & \\
\hline \multicolumn{6}{|l|}{ Correlations } \\
\hline & & & \multicolumn{2}{|c|}{ Overall Knowledge } & Sum_All_Behavior \\
\hline \multirow[t]{3}{*}{ Overall Knowledge } & \multicolumn{2}{|c|}{ Pearson Correlation } & \multicolumn{2}{|l|}{1} & -.335 \\
\hline & \multicolumn{2}{|c|}{ Sig. (1-tailed) } & & & .111 \\
\hline & \multicolumn{2}{|l|}{$N$} & \multicolumn{2}{|l|}{15} & 15 \\
\hline \multirow[t]{3}{*}{ Sum_All_Behavior } & \multirow{2}{*}{\multicolumn{2}{|c|}{$\begin{array}{l}\text { Pearson Correlation } \\
\text { Sig. (1-tailed) }\end{array}$}} & \multirow{2}{*}{\multicolumn{2}{|c|}{-.335}} & 1 \\
\hline & & & & & .111 \\
\hline & \multicolumn{2}{|l|}{$N$} & \multicolumn{2}{|l|}{15} & 15 \\
\hline
\end{tabular}

Predictive Utility of Age, Taking Finance Related Subject in High School, Financial Literacy Level With Respect to Financial Behavior

This paper conducted a multivariate linear regression to investigate the predictive utility of age (using year of study as the proxy), taking finance related subject in high school, financial literacy level with respect to financial behavior. Again, student respondents with credit card are taken into the investigation.

Regression analysis is a common data analysis method to support the model's predictive power assessment, which is informed by the $R^{2}$ of the model regarding the percentage of the variance explained by independent variables. Also, which independent variables are the significant predictor(s) of the dependent variable are informed by the respective beta coefficient, $t$-value and the $p$-value (Hair, Anderson, Tatham, \& Black, 1998; Isomidinova et al., 2017).

The results revealed that they are not significant predictor of financial behavior. The amount of explained variance is insignificant $F(3,11)=0.715, p>.05$, rejecting Hypothesis 6.

TABLE 7. Multivariate linear regression analysis for hypothesis 6

\begin{tabular}{|c|c|c|c|c|c|}
\hline \multicolumn{6}{|c|}{ Model Summary } \\
\hline Model & $\boldsymbol{R}$ & \multicolumn{2}{|c|}{$R$ Square } & Adjusted $R$ Square & Std. Error of the Estimate \\
\hline 1 & $.404^{\mathrm{a}}$ & \multicolumn{2}{|c|}{.163} & -.065 & 1.55375 \\
\hline \multicolumn{6}{|c|}{ a. Predictors: (Constant), overallKnowledge, take_notTake, Yr_of_study_10.1 } \\
\hline \multicolumn{6}{|l|}{ ANOVA $^{\mathrm{a}}$} \\
\hline Model & \multicolumn{2}{|c|}{ Sum of Squares } & $d f$ & Mean Square & Sig. \\
\hline 1 Regression & \multicolumn{2}{|l|}{5.178} & 3 & 1.726 & $.563^{\mathrm{b}}$ \\
\hline Residual & \multicolumn{2}{|l|}{26.556} & 11 & 2.414 & \\
\hline Total & \multicolumn{2}{|l|}{31.733} & 14 & & \\
\hline
\end{tabular}

\begin{tabular}{llllll}
\hline Coefficients $^{\mathbf{a}}$ & \multicolumn{2}{l}{} & & \\
\hline Model & Unstandardized Coefficients & Unstandardized Coefficients & $\boldsymbol{t}$ & Sig. \\
& $\boldsymbol{B}$ & Std. Error & & & \\
\hline 1 (Constant) & 16.806 & 4.991 & & 3.367 & .006 \\
Yr_of_study_10.1 & .639 & 1.255 & .149 & .509 & .621 \\
Take_notTake & .722 & 1.215 & .169 & .595 & .564 \\
Over all Knowledge & -.861 & .607 & -.421 & -1.418 & .184 \\
\hline \hline
\end{tabular}

aa. Dependent Variable: Sum_All_Behavior 


\section{DISCUSSION, IMPLICATIONS AND FUTURE RESEARCH DIRECTIONS}

Table 8 summarized the preliminary hypothesis testing results from this pilot study.

\section{Practical Implications}

From this pilot study, comprehensible questionnaire items were developed, together with the selected questions de- veloped by the Jump\$tart Coalitation for Personal Financial Literacy, it formulated a measurement instrument with appropriate length that fit into the fast pace of life of the high school and higher education students groups that can secure a satisfactory response and completion rate. This paves the way for the full-scale investigation of the research focus.

TABLE 8. Summary of the hypotheses testing results

\begin{tabular}{l}
\hline \hline The Hypothesis \\
\hline Hypothesis 1: Teachers, students and other stakeholders have the same perception of the effectiveness of financial education \\
at high schools in supporting youngsters to handle personal finance issues. \\
Hypothesis 2: Teachers, students and other stakeholders have similar view that personal finance subject should be offered in \\
higher education institutions for all their students. \\
Hypothesis 3: Students taking finance related courses or activities at high schools have higher financial literacy. \\
Hypothesis 4: Students taking finance related courses or activities in university have higher financial literacy. \\
Hypothesis 5: There is correlation between financial literacy and financial behavior for tertiary level students. \\
Hypothesis 6: Age, taking finance related subject in high school and financial literacy level are significant predictor of financial \\
behavior.
\end{tabular}

\section{Theoretical Implications}

The preliminary findings confirmed that teachers, students and other stakeholders share the same perception of the effectiveness of financial education at high schools in supporting youngsters to handle personal finance issues. In addition, they have similar view that personal finance subject should be offered in higher education institutions for all their students. The results are consistent with the common believe identified from previous research that there is value to offer financial education courses at high schools (Investor Education Centre, 2016; Lechner et al., 2018) and at higher education levels (Goetz et al., 2011). Furthermore, it supports the argument that teachers affect students' beliefs e.g., (Nolen \& Haladyna, 1990), and that the youngsters at university level normally wants to learn more about financial knowledge (Lusardi et al., 2010). This is also true for other stakeholders since it is a common phenomenon that university students are found lacking financial management skills (Atakora, 2013; Nellie, 2002; Norvilitis et al., 2006). No one want to see graduating students are not ready to handle personal finance issues, which may have a negative impact not only to the individuals but also to the society as a whole.

Hypothesis 3 and 4 were supported in this preliminary investigation. The investigation is a response to the call for more evidence support of financial education effectiveness (Isomidinova et al., 2017; Lusardi et al., 2010). The findings align with previous researches that taking courses in personal finance, business or economics could improve student's financial knowledge (Albeerdy \& Gharleghi, 2015; Asarta et al., 2014; Chen \& Volpe, 2002; Cude, 2010; Danes
\& Haberman, 2007; Lusardi et al., 2010; Peng et al., 2007; Taft et al., 2013; Varcoe et al., 2005; Walstad et al., 2010). Should a full-scale research be conducted, it could provide further empirical support to such argument.

Hypothesis 5 and 6 were not supported in this preliminary investigation. Although previous researches focusing on adults found that a high level of financial literacy has a positive impact on management of personal finances (Capuano \& Ramsay, 2011; Lusardi et al., 2010), this pilot study alerts that those findings may not be generalizable to the tertiary level students. One possible explanation is that although talking financial education training could bring about behavioral change, it may be short-term impact (Danes et al., 1999). Another explanation is that youngsters after taking fundamental courses in financial education may result in overconfidence towards financial matters and making improper decision (De Zwaan et al., 2017). Furthermore, youngsters in this new era are easily influenced by the regular and repeating marketing promotion that stimulate their financial behavior such as consumption and credit card usage, offsetting the effect of financial literacy factors. This echoed Seiling and Shockey (2006) argument that financial education may not always result in behavior change because of other constraints or interfering factors. These preliminary findings also contradict with previous research focused on the correlation or causality of financial literacy level and financial behavior e.g., (Courchane \& Zorn, 2005; Hilgert et al., 2003; Kotlikoff, 2016). Should a full-scale research report the same findings, the generalizability of those findings to the youngsters could be a doubt. Specif- 
ically, although the age and levels of education has association with financial literacy level, age is not a predictor of financial behavior. The possible reason is that although age increase with knowledge accumulation from practical life experience, but age increase may not guarantee proper financial behavior because cognitive functions deterioration could be possible (Agarwal, Driscoll, Gabaix, \& Laibson, 2007; Ansong \& Gyensare, 2012).

\section{CONCLUSION}

To conclude, the value of this pilot study research is to shed light on the possible research design to investigate whether young generation are well prepared with the basic financial knowledge to handle the personal finance issues. The preliminary findings informed the policy makers, education sectors, social science researchers and banking and finance practitioners on the needs to enhance the financial literacy of the new generation for the well-being of the individuals as well as the society. It also arouses the possible need of providing highly target and well-specified programme incorporating the practical application of financial skills in daily life for the young generation (Hathaway \& Khatiwada, 2008; International Network on Financial Education, 2011; Walstad et al., 2010).

\section{Limitations and recommendations}

As a pilot test, this investigation invited only 39 respondents comprising high school students, high school teachers and counsellor and university students. The sample size was too small. In addition, to reduce the time required to complete the questionnaire in order to increase the responding rate, only three selected items, but not all the items, developed by the Jump Start Coalitation for Personal Financial Literacy were used.

The major drawback of the pilot testing is that the results are far from generalizable to the wider population. To improve the reliability of the investigation, further research should consider a bigger sample and more balanced mix of different types of respondents. Take the Hong Kong context as an example, with upper secondary (high school) population size of over 1.9 million and sub-degree and degree level population of over 1.7 million (Hong Kong Government, 2016) respective sample size of around 380 are highly recommended if the research aims at achieving a confidence level of $95 \%$ and a margin of error of $+/-5 \%$ (Cochran, 2007; Krejcie \& Morgan, 1970; Rea \& Parker, 2014). Furthermore, a few more items developed by the Jump\$tart Coalitation for Personal Financial Literacy might be used to improve the reliability of the findings, but it should weight against the impact on the response and completion rate especially in the research context with fast pace of life and with the youths as the target respondents. In addition, more advanced statistical tests should be conducted to explore what other factors could determine the financial behavior, and the inter-relationship among variables.

In this pilot study, although students taking subject related to finance at either high school or in universities exhibit higher financial literacy, there is no positive effect of the level of financial literacy on their financial behaviour. The perceived effectiveness of finance related subjects at high school level in supporting university students in handling personal finance matters was just average for both teachers and students. Furthermore, this pilot study found that some previous research findings relevant for adults may not be applicable to youngsters, as nowadays they may not only be influenced by education programmes but by the active marketing promotion activities of businesses and financial services providers which impact their financial behaviour. This alerts educators and curriculum developers the possible need to design and offer a more specific personal finance subject focusing on enlightening how to put the financial knowledge into personal finance issues for the students well-being, especially in the new era of e-commerce and fintech which make consumption, expenditure payment and subscription to financial products and services easier for the young generation. This could also cope with the expectation of teachers, students and other stakeholders according to the research findings.

\section{REFERENCES}

Agarwal, S., Driscoll, J. C., Gabaix, X., \& Laibson, D. (2007). The age of reason: Financial decisions over the lifecycle (Tech. Rep.). National Bureau of Economic Research, Cambridge, MA.

Albeerdy, M. I., \& Gharleghi, B. (2015). Determinants of the financial literacy among college students in Malaysia. International Journal of Business Administration, 6(3), 51-54. doi:https://doi.org/10.5430/ijba.v6n3p15

Ansong, A., \& Gyensare, M. A. (2012). Determinants of university working-students' financial literacy at the university of Cape Coast, Ghana. International Journal of Business and Management, 7(9), 126-130. doi:https://doi.org/10.5539/ ijbm.v7n9p126 
Asarta, C. J., Hill, A. T., \& Meszaros, B. T. (2014). The features and effectiveness of the keys to financial success curriculum. International Review of Economics Education, 16(2), 39-50. doi:https://doi.org/10.1016/j.iree.2014.07.002

Atakora, A. (2013). Measuring the effectiveness of financial literacy programs in Ghana. International Journal of Management and Business Research, 3(2), 135-148.

Bewick, V., Cheek, L., \& Ball, J. (2004). Statistics review 9: One-way analysis of variance. Critical Care, 8(2), 130-136.

Capuano, A., \& Ramsay, I. (2011). What causes suboptimal financial behaviour? An exploration of financial literacy, social influences and behavioural economics (Working paper No. 50). University of Melbourne Legal Studies Research, Melbourne, Australia.

Carnevale, D. (2003). Learning online to teach online. Chronicle of Higher Education, 50(10), 98-105. doi:https://doi.org/ $10.1177 / 088840640302600203$

Chen, H., \& Volpe, R. P. (2002). Gender differences in personal financial literacy among college students. Financial Services Review, 11(3), 289-307.

Cochran, W. G. (2007). Sampling techniques. New York, NY: John Wiley \& Sons.

Courchane, M., \& Zorn, P. (2005). Consumer literacy and credit worthiness. In Proceedings, Federal Reserve Bank of Chicago, New York, NY.

Cude, B. J. (2010). Financial literacy 501. Journal of Consumer Affairs, 44(2), 271-275. doi:https://doi.org/10.1111/ j.1745-6606.2010.01168.x

Danes, S. M., \& Haberman, H. (2007). Teen financial knowledge, self-efficacy, and behavior: A gendered view. Journal of Financial Counseling and Planning, 18(2), 48-60.

Danes, S. M., Huddleston-Casas, C., \& Boyce, L. (1999). Financial planning curriculum for teens: Impact evaluation. Journal of Financial Counseling and Planning, 10(1), 26-30. doi:https://doi.org/10.1891/1052-3073.27.1.61

De Zwaan, L., Palm, C. T., Liu, Y., \& Chardon, T. (2017). Overconfidence in financial literacy: Implications for planners. Financial Planning Research Journal, 3(2), 31-46.

Goetz, J. W., Cude, B. J., Nielsen, R. B., Chatterjee, S., \& Mimura, Y. (2011). College-based personal finance education: Student interest in three delivery methods. Journal of Financial Counseling and Planning, 22(1), 27-42. doi:https://doi.org/ $10.2139 /$ ssrn.2782788

Gudmundsdottir, G. B., \& Brock-Utne, B. (2010). An exploration of the importance of piloting and access as action research. Educational Action Research, 18(3), 359-372.

Hair, J. F., Anderson, R. E., Tatham, R. L., \& Black, W. C. (1998). Multivariate data analysis. New Jersey, NJ: Printice-Hall.

Hathaway, I., \& Khatiwada, S. (2008). Do financial education programs work? (Working paper No. 08). Federal Research Bank of Cleveland, Cleveland, Ohio.

Hilgert, M. A., Hogarth, J. M., \& Beverly, S. G. (2003). Household financial management: The connection between knowledge and behavior. Federal Reserve Bulletin, 89(6), 309-322.

Hong Kong Government. (2016). 2016 population by-census summary results (Technical report). Census and Statistics Department, Hong Kong Special Administrative Region, Hong Kong, China.

International Network on Financial Education. (2011). Measuring financial literacy: Questionnaire and guidance notes for conducting an internationally comparable survey of financial literacy. Retrieved from https://bit.1y/2Ub6L5P

Investor Education Centre. (2014). IEC research: Understanding financial literacy in schools. Retrieved from https:// bit.ly/37AbGkF

Investor Education Centre. (2016). Practical personal financial planning programme: Evaluation findings. Retrieved from https://bit.1y/3aQjLE1

Isomidinova, G., Singh, J. S. K., \& Singh, K. (2017). Determinants of financial literacy: A quantitative study among young students in Tashkent, Uzbekistan. Electronic Journal of Business \& Management, 2(1), 61-75.

Kamran, M. R., \& Z, Z. (2016). Millennium \& financial development goals: Economic indicators perspective of South Asian countries. International Journal of Humanities, Arts and Social Sciences, 2(4), 133-151. doi:https://doi.org/10.20469/ ijhss.2.20003-4

Kotlikoff, L. J. (2016). Essays on saving, bequests, altruism, and life-cycle planning. Cambridge, MA: MIT Press.

Krejcie, R. V., \& Morgan, D. W. (1970). Determining sample size for research activities. Educational and Psychological Measurement, 30(3), 607-610. doi:https://doi.org/10.1177/001316447003000308 
Lechner, G., Craß, N., Kraleva, D., Scharer, V., Iwański, J., \& Giraud, S. (2018). Financial education for child and youth care practitioners. Journal of Accounting, Business and Finance Research, 2(2), 55-63. doi:https://doi.org/10.20448/ 2002.22.55.63

Lusardi, A., Mitchell, O. S., \& Curto, V. (2010). Financial literacy among the young. Journal of Consumer Affairs, 44(2), 358-380. doi:https://doi.org/10.1257/jel.52.1.5

Lusardi, A., \& Tufano, P. (2009). Debt literacy, financial experiences, and overindebtedness. Retrieved from https : //bit . ly/ $3 \mathrm{aXq} 4 \mathrm{FB}$

Mandell, L., \& Klein, L. S. (2009). The impact of financial literacy education on subsequent financial behavior. Journal of Financial Counseling and Planning, 20(1), 15-24.

Masuo, D., \& Cheang, M. (2017). Disconnect between parents' values for saving and actual savings behavior: Impact on children's education and financial decision-making. Journal of Advances in Humanities and Social Sciences, 3(6), 332-339. doi:https://doi.org/10.20474/jahss-3.6.5

Nellie, M. (2002). Undergraduate students and credit cards: An analysis of usage and trends. Braintree, MA: Sage Publications.

Nolen, S. B., \& Haladyna, T. M. (1990). Personal and environmental influences on students' beliefs about effective study strategies. Contemporary Educational Psychology, 15(2), 116-130. doi:https://doi.org/10.1016/0361-476x(90)90011-o

Norvilitis, J. M., Merwin, M. M., Osberg, T. M., Roehling, P. V., Young, P., \& Kamas, M. M. (2006). Personality factors, money attitudes, financial knowledge, and credit-card debt in college students 1. Journal of Applied Social Psychology, 36(6), 1395-1413. doi:https://doi.org/10.1111/j.0021-9029.2006.00065.x

Peng, T.-C. M., Bartholomae, S., Fox, J. J., \& Cravener, G. (2007). The impact of personal finance education delivered in high school and college courses. Journal of Family and Economic Issues, 28(2), 265-284. doi:https://doi.org/10.1007/ s10834-007-9058-7

Rea, L. M., \& Parker, R. A. (2014). Designing and conducting survey research: A comprehensive guide. Francisco, CA: John Wiley \& Sons.

Robb, C. A., \& Sharpe, D. L. (2009). Effect of personal financial knowledge on college students' credit card behavior. Journal of Financial Counseling and Planning, 20(1), 25-43.

Seiling, S., \& Shockey, S. (2006). Financial education and stages of behavior change: Evidence from an IDA program. The Journal of Consumer Education, 23, 27-36.

Stone, D. N., Wier, B., \& Bryant, S. M. (2008). Reducing materialism through financial literacy. The CPA Journal, 78(2), $12-14$. doi:https://doi.org/10.1037/t31249-000

Taft, M. K., Hosein, Z. Z., Mehrizi, S. M. T., \& Roshan, A. (2013). The relation between financial literacy, financial wellbeing and financial concerns. International Journal of Business and Management, 8(11), 63-75. doi:https://doi.org/10.5539/ ijbm.v8n11p63

Varcoe, K., Martin, A., Devitto, Z., \& Go, C. (2005). Using a financial education curriculum for teens. Journal of Financial Counseling and Planning, 16(1), 63-71. doi:https://doi.org/10.1891/1052-3073.26.1.102

Walstad, W. B., Rebeck, K., \& MacDonald, R. A. (2010). The effects of financial education on the financial knowledge of high school students. Journal of Consumer Affairs, 44(2), 336-357. doi:https://doi.org/10.1111/j.1745-6606.2010.01172 .X

Xiao, J. J. (2008). Applying behavior theories to financial behavior. In Handbook of consumer finance research. New York, NY: Springer.

Yilmaz, D. V. (2017). International student recruitment in policy and practice: A research from Turkey. Journal of Advanced Research in Social Sciences and Humanities, 2(1), 01-08. doi:https://doi.org/10.26500/jarssh-02-2017-0101

Zakaria, R., Jaafar, B., \& Marican, S. (2012). Financial behavior and financial position: A structural equation modelling approach. Middle-East Journal of Scientific Research, 11(5), 602-609. 